\title{
Variability Associated with Suppression of Gray Mold (Botrytis cinerea) on Geranium by Foliar Applications of Nonaerated and Aerated Compost Teas
}

\author{
Steven J. Scheuerell, Department of Botany and Plant Pathology, Oregon State University, and Walter F. Mahaffee, \\ United States Department of Agriculture - Agriculture Research Service - Horticulture Crops Research Laboratory, \\ 3420 NW Orchard Ave., Corvallis, OR 97330
}

\begin{abstract}
Scheuerell, S. J., and Mahaffee, W. F. 2006. Variability associated with suppression of gray mold (Botrytis cinerea) on geranium by foliar applications of nonaerated and aerated compost teas. Plant Dis. 90:1201-1208.

The use of compost teas in agriculture and urban landscapes is increasing, but there is conflicting information on which methods are suitable for obtaining compost teas that suppress disease when applied to plants. Numerous compost tea production parameters (compost source, aeration, nutrient additives, production duration, and use of application adjuvants) were tested for suppressing gray mold (Botrytis cinerea) on geranium. While individual compost tea batches did significantly reduce disease, the majority of compost teas did not significantly suppress gray mold of geranium. For nonaerated compost tea (NCT), the most consistent, significant disease suppression was associated with particular compost samples and increased production time, with little effect of periodic stirring or the addition of nutrients at the onset of production. Continuously aerating compost tea did not significantly increase disease suppression compared with nonaerated compost teas. Preparing aerated compost tea (ACT) with nutrient additives did not consistently increase disease suppression; however, $67 \%$ of ACT batches made with a mixture of kelp extract, rock dust, and humic acid significantly reduced disease. Applying ACT with spray adjuvants significantly reduced disease compared with ACT with no adjuvants. The variability in gray mold suppression from NCT and ACT applications indicates that disease control would not be commercially acceptable unless there are no other alternatives due to production constraints, e.g., organic standards.
\end{abstract}

Additional keywords: compost extract, watery-fermented compost extract

Gray mold, caused by Botrytis cinerea Pers.:Fr., affects a wide range of ornamental and edible crops (8). Commercially acceptable levels of disease control have been attained principally by fungicide applications and, to a lesser extent, through environmental modification (14). Due to increased development of fungicideresistant isolates $(15,24,41)$, potential regulatory loss of fungicides, worker health and safety concerns, and reduced worker productivity during the re-entry intervals after fungicide applications, alternative disease control measures are needed.

One alternative approach has been to treat plants with nonaerated compost teas (NCT) (synonyms: compost extracts [36] or watery-fermented compost extracts [38]). Production and use of NCT is typically done by mixing compost, water, and

Corresponding author: W. F. Mahaffee

E-mail: mahaffew@science.oregonstate.edu

Accepted for publication 5 May 2006.

DOI: 10.1094/PD-90-1201

This article is in the public domain and not copyrightable. It may be freely reprinted with customary crediting of the source. The American Phytopathological Society, 2006. optional nutrient additives in an open container, leaving it undisturbed for a defined number of days, and then applying it to plants (38). Application of NCT has been shown to significantly suppress gray mold on bean leaves $(23,34)$, grape leaves and berries $(10,17)$, lettuce (23), strawberry fruit $(33,34)$, and tomato and pepper foliage (10).

There are numerous compost tea production parameters (e.g., aeration, compost source, nutrient additives, production duration, and spray adjuvants) that have been manipulated in attempts to optimize plant disease suppression $(30,38)$. Initial reports focused on only one or a few of these production parameters, and consensus has not been reached on optimal compost tea production parameters for plant disease suppression. For instance, early reports on the role of compost source indicated that manure-based composts were most efficacious (38). However, Elad and Shtienberg (10) determined that NCT made using grape marc compost was as effective as using manure-based compost to inhibit $B$. cinerea on foliage in greenhouse assays. Similarly, producing NCT with or without nutrient additives has had variable effects on $B$. cinerea suppression. Urban and Tränkner (34) reported that preparing NCT with 5 to $7 \mathrm{~g}$ of peptone or yeast extract per liter inhibited B. cinerea up to $100 \%$, while starch and sucrose additions were less effective. In contrast, Elad and Shtienberg (10) found no significant suppression of $B$. cinerea when NCT was prepared with an unstated quantity of nutrient broth. Another variable is the wide range in NCT fermentation times reported to maximize suppression of $B$. cinerea. Ketterer et al. (17) reported that 7-day-old NCT was optimal across three compost sources for suppressing $B$. cinerea on detached grape leaves. However, Elad and Shtienberg (10) observed that 14-day-old NCT was consistently more suppressive than 7-day-old NCT across three compost sources when applied to detached grape berries, pepper leaves, and tomato leaves. These inconsistencies make developing practical protocols for compost tea use in agriculture difficult.

More recently, variations in compost tea production methods have been introduced that could further modify the potential for compost tea to suppress $B$. cinerea. One modification is to mix NCT by stirring every 2 to 3 days over the production period to possibly facilitate the release of microbes from compost particles (6). However, the effect of periodic mixing of NCT on plant disease suppression has not been assessed. Another untested variable is the possibility that NCT removed from different depths of an open production container could have differential disease suppression activity due to the aerobic, microaerobic, and anaerobic gradients of oxygen found in open fermentation vessels (15).

A recently introduced compost tea production parameter is continuously aerating compost tea during production. Aerated compost tea (ACT) production has become widely practiced, with a parallel increase in anecdotal reports of disease suppression $(11-13,25)$. For ACT, it has been proposed that rapidly increasing microbial populations with nutrient additives and forced aeration will generally increase plant disease suppression (11). Few published studies have examined the potential for ACT to suppress plant diseases (30). Only one published study has attempted to compare ACT and NCT for the reduction of $B$. cinerea; however, due to insufficient natural disease pressure during the singleseason study, no significant differences were detected across treatments on the 
percentage of strawberry fruit infected by B. cinerea (35).

There is also the possibility that postproduction parameters could impact disease suppression by applications of compost teas. Spray adjuvants added to NCT have significantly increased $B$. cinerea suppression. Casein $(0.5 \% \mathrm{vol} / \mathrm{vol})$ and pine oil $(0.05 \% \mathrm{vol} / \mathrm{vol})$ added to NCT significantly increased suppression of $B$. cinerea on grape berries when applied over the growing season (17).

The goal of this work was to develop practical recommendations for the use of compost teas for control of gray mold in nursery crop production; thus, many of the practices for commercial compost storage, tea production, and plant management were simulated at a smaller scale. Initially, this research focused on NCT production parameters, but it was expanded to include ACT production due to variability in disease control observed using NCT. The objectives of this study were to: (i) determine whether the compost tea production parameters compost source, nutrient additives, production duration, incremental mixing during production, and depth of liquid in the production container are important for suppression of gray mold $(B$. cinerea) on geranium (Pelargonium $\times$ hortorum) foliage; (ii) determine if ACT is more effective than NCT when produced from the same compost source with or without nutrient additives; (iii) examine if nutrient additives affect ACT disease suppression and culturable bacterial populations; and (iv) determine if the addition of spray adjuvants to ACT enhances disease suppression.

\section{MATERIALS AND METHODS}

Compost sample collection. Compost samples $(N=29)$ were collected at commercial composting facilities in western Oregon from stockpiled material considered ready for sale by the facility operator. These compost samples included the major types of commercially available compost in Oregon and Washington. The samples encompassed a wide range of compost substrates, ages, $\mathrm{pH}$, electrical conductivity (EC), moisture content, and bacterial and fungal populations (Table 1). Compost feedstock ratios were provided by the facility operator and used to categorize each compost sample into a compost class (Table 1). In order to generate a sample representative of the entire compost pile, a composite sample was created by removing arbitrarily four cores dug $1.0 \mathrm{~m}$ deep from each pile. The cores were placed in a 19-liter bucket or 45-liter plastic bin and mixed. These containers were then stored outside in a covered structure, similar to what would occur in commercial production. While the physical, chemical, and microbial structure of the compost are known to change over time (40), the storage conditions used in this study represent standard commercial production practices and therefore represent the variability associated with commercial compost tea production. Each compost was used in experiments as received and then periodi-

Table 1. Characteristics of compost sources used to make compost tea

\begin{tabular}{|c|c|c|c|c|c|c|c|c|c|}
\hline $\begin{array}{l}\text { Compost } \\
\text { sample }\end{array}$ & $\begin{array}{l}\text { Compost } \\
\text { class }\end{array}$ & Compost feedstocks & $\begin{array}{l}\text { Sample } \\
\text { date }\end{array}$ & $\begin{array}{c}\text { Age } \\
\text { (days) }\end{array}$ & $\mathbf{p H}^{\mathbf{v}}$ & $\mathbf{E C}$ & $\begin{array}{l}\text { Mois- } \\
\text { ture }^{\mathrm{x}}\end{array}$ & $\begin{array}{l}\text { Bacteria } \\
\text { CFU/ml } \\
\left(\times 10^{6}\right)^{y}\end{array}$ & $\begin{array}{c}\text { Fungi } \\
\text { CFU/ml } \\
\left(\times 10^{3}\right)^{z}\end{array}$ \\
\hline 1 & Bark & $\begin{array}{l}\text { Mixed bark+landscape plants+biosolids (proprietary } \\
\text { ratio) }\end{array}$ & $8 / 20 / 1999$ & 180 & 5.15 & 0.51 & 69 & 84 & 452 \\
\hline 2 & Bark & $\begin{array}{l}\text { Douglas Fir bark+gravity belt separated dairy solids } \\
(3: 1 \mathrm{vol} / \mathrm{vol})\end{array}$ & $8 / 13 / 1999$ & 75 & 5.35 & 0.10 & 64 & 167 & 5,830 \\
\hline 3 & Blend & Proprietary blend of manure and vegetative composts & $5 / 15 / 2001$ & 120 & 6.90 & 3.52 & 51 & 135 & 5 \\
\hline 4 & Chicken & Sawdust+rice hulls+chicken manure $(2: 1: 1 \mathrm{vol} / \mathrm{vol})$ & $12 / 16 / 1998$ & 105 & 8.34 & 2.42 & 61 & 1,540 & 35,900 \\
\hline 5 & Chicken & Sawdust+rice hulls+chicken manure $(2: 1: 1 \mathrm{vol} / \mathrm{vol})$ & 2/16/1999 & 165 & 7.61 & 2.01 & 64 & 147 & 61,100 \\
\hline 6 & Chicken & Sawdust+rice hulls+chicken manure $(2: 1: 1 \mathrm{vol} / \mathrm{vol})$ & $2 / 16 / 1999$ & 105 & 7.53 & 1.92 & 64 & 89 & 111 \\
\hline 7 & Chicken & Sawdust+rice hulls+chicken manure $(2: 1: 1 \mathrm{vol} / \mathrm{vol})$ & $4 / 19 / 1999$ & 170 & 8.10 & 3.75 & 61 & 6 & 1 \\
\hline 8 & Chicken & Sawdust+rice hulls+chicken manure $(2: 1: 1 \mathrm{vol} / \mathrm{vol})$ & $5 / 26 / 1999$ & 200 & 6.39 & 4.06 & 58 & 38 & 95 \\
\hline 9 & Chicken & Sawdust+rice hulls+chicken manure $(2: 1: 1 \mathrm{vol} / \mathrm{vol})$ & $3 / 22 / 2000$ & 165 & 6.19 & 3.69 & 68 & 625 & 11,300 \\
\hline 10 & Chicken & Sawdust+yard trimmings+chicken manure $(1: 1: 1)$ & $10 / 21 / 1998$ & 70 & 8.15 & 3.69 & 59 & 2 & $\mathrm{Nd}$ \\
\hline 11 & Chicken & Sawdust+yard trimmings+chicken manure $(1: 1: 1)$ & $12 / 16 / 1998$ & 67 & 7.25 & 1.84 & 61 & 795 & 1,490 \\
\hline 12 & $\mathrm{CMC}$ & $\begin{array}{l}\text { Straw, sawdust, pome fruit, manure, clay soil } \\
\quad(2: 2: 2: 2: 1 \mathrm{vol} / \mathrm{vol})\end{array}$ & 2/16/1999 & 160 & 7.10 & 1.42 & 31 & 26 & 6 \\
\hline 13 & $\mathrm{CMC}$ & $\begin{array}{l}\text { Straw, sawdust, pome fruit, manure, clay soil } \\
\quad(2: 2: 2: 2: 1 \mathrm{vol} / \mathrm{vol})\end{array}$ & $5 / 27 / 1999$ & 65 & 8.10 & 0.53 & 48 & 3 & $\mathrm{Nd}$ \\
\hline 14 & Dairy & Straw, dairy manure, eggshells (20:10:1 vol/vol) & $10 / 20 / 1998$ & 95 & 7.85 & 4.15 & 63 & 1,460 & 92 \\
\hline 15 & Dairy & Dairy manure, bedding, fish waste $(2: 2: 1 \mathrm{vol} / \mathrm{vol})$ & 4/23/1999 & 65 & 8.84 & 10.05 & 69 & 903 & $\mathrm{Nd}$ \\
\hline 16 & Micronized & $\begin{array}{l}\text { Ground plants, hay, horse and cow manure, lime } \\
(10: 5: 5: 5: 1)\end{array}$ & $8 / 3 / 1999$ & 120 & 7.91 & 5.95 & 8 & 1 & 2 \\
\hline 17 & Mint blend & Bark, sawdust, mixed manure, mint $(2: 2: 2: 1 \mathrm{vol} / \mathrm{vol})$ & $12 / 16 / 1998$ & 74 & 7.94 & 1.86 & 53 & 1,190 & 5,960 \\
\hline 18 & Steer blend & $\begin{array}{l}\text { Proprietary blend, manures and bulking agents } \\
(1: 1 \mathrm{vol} / \mathrm{vol})\end{array}$ & $10 / 21 / 1998$ & 390 & 7.43 & 2.47 & 48 & 454 & 1,080 \\
\hline 19 & Steer blend & $\begin{array}{l}\text { Proprietary blend, manures and bulking agents } \\
\quad(1: 1 \mathrm{vol} / \mathrm{vol})\end{array}$ & $12 / 16 / 1998$ & 90 & 6.14 & 2.64 & 38 & 345 & 16,100 \\
\hline 20 & Vermicompost & Cow manure + food waste + paper $(1: 1: 1 \mathrm{vol} / \mathrm{vol})$ & $3 / 20 / 2000$ & 90 & 6.43 & 5.56 & 78 & 155 & 1,270 \\
\hline 21 & Vermicompost & Vegetative food waste, paper $(1: 1 \mathrm{vol} / \mathrm{vol})$ & $8 / 28 / 2001$ & 120 & 6.03 & 4.70 & 42 & 1 & 43 \\
\hline 22 & Vermicompost & Straw, dairy manure, eggshells (20:10:1 vol/vol) & $10 / 20 / 1998$ & 160 & 7.20 & 3.75 & 67 & 1,150 & 2,360 \\
\hline 23 & Yard trimmings & Ground landscape plants & $12 / 16 / 1998$ & 108 & 6.58 & 0.50 & 59 & 1,560 & 585 \\
\hline 24 & Yard trimmings & Ground landscape plants & 4/19/1999 & 40 & 6.98 & 0.78 & 66 & 282 & 100 \\
\hline 25 & Yard trimmings & Ground landscape plants & $10 / 21 / 1998$ & 85 & 6.86 & 1.07 & 46 & 106 & 56 \\
\hline 26 & Yard trimmings & Ground landscape plants & $12 / 16 / 1998$ & 105 & 6.75 & 0.52 & 60 & 1,000 & 550 \\
\hline 27 & Yard trimmings & Ground landscape plants & 2/16/1999 & 110 & 7.49 & 0.52 & 64 & 91 & $\mathrm{Nd}$ \\
\hline 28 & Yard trimmings & Ground landscape plants & $4 / 19 / 1999$ & 68 & 7.78 & 0.37 & 62 & 74 & 21 \\
\hline 29 & Yard trimmings & Ground landscape plants & $5 / 25 / 1999$ & 280 & 7.22 & 0.37 & 62 & 118 & 237 \\
\hline 30 & Yard trimmings & Ground landscape plants+chicken manure (10:1 vol/vol) & $12 / 16 / 1998$ & 137 & 7.12 & 0.93 & 49 & 3,820 & 275 \\
\hline
\end{tabular}

${ }^{\mathrm{v}}$ Compost $\mathrm{pH}$ was determined from a saturated paste using a portable $\mathrm{pH}$ meter (model 150, IQ Scientific Instruments).

${ }^{w}$ Electrical conductivity (EC) was determined from compost and deionized water (2:1 vol/vol) with a portable EC meter (model 933100, Hanna Instruments).

${ }^{\mathrm{x}}$ Determined from weight loss of compost $(50 \mathrm{~g})$ dried for $36 \mathrm{~h}$ at $70^{\circ} \mathrm{C}$ in a forced air oven.

${ }^{y}$ Bacteria enumerated on $5 \%$ trypticase soy broth agar with cycloheximide $(100 \mu \mathrm{g} / \mathrm{ml})$. Populations reported as CFU/dry g of compost.

${ }^{\mathrm{z}}$ Fungi enumerated on water agar, $\mathrm{pH}$ 6, with rifampicin $(50 \mu \mathrm{g} / \mathrm{ml})$. Populations reported as CFU/dry g of compost. 
cally over time, similar to how compost is used in commercial nursery production. Individual experiments may or may not have contained more than one compost sample, with individual or several production parameters being manipulated. All experiments were factorial designs of compost source, production method, nutrient amendment, or spray adjuvants in various combinations of factors.

Compost tea production. Nonaerated compost tea production. NCT was produced with a 5:1 water:compost ratio $(\mathrm{vol} / \mathrm{vol})$ in a round, 2-liter plastic container $(1,500 \mathrm{ml}$ of water) or in 19-liter plastic buckets (10 liters of water). Where indicated, a limited number of NCT were produced with 15 liters of water and $500 \mathrm{~g}$ of compost (wet weight, approximately $25: 1, \mathrm{vol} / \mathrm{vol}$ ) in a 19 -liter plastic bucket. Tap water was placed in a container and allowed to sit for $24 \mathrm{~h}$ before being used to allow for passive reduction of chlorine (39). When used, nutrient additives were mixed into the water, followed by addition of compost. Nutrient additives consisted of either $0.3 \%$ molasses (Aunt Pattie's Blackstrap; Glorybee Foods, Eugene, OR), 0.3\% (wt/vol) hydrolyzed yeast powder (Red Star Yeast Co., Milwaukee, WI), $0.5 \%$ (vol/vol) Bacterial Nutrient Solution (Soil Soup, Inc., Edmonds, WA), proprietary blend of molasses, kelp, and trace materials, or fungal nutrient mixture $(1.2 \mathrm{~g}$ of powdered soluble kelp (20) [Maxicrop USA, Inc., Elk Grove Village, IL], $2.5 \mathrm{ml}$ of liquid humic acids [Humax, JH Biotech, Inc., Ventura, CA], and $3 \mathrm{~g}$ of rock dust [Target Glacial Dust, Target Products Ltd., Burnaby, B.C.] [13]). The entire brewer contents were vigorously stirred by hand for $20 \mathrm{~s}$ with a sterile glass rod and then left undisturbed for 7 or 14 days until application. To examine the effect of periodic mixing NCT, designated containers were stirred for $20 \mathrm{~s}$ at 3 and 5 days after initial mixing and then applied on the seventh day. Normally, NCT were prepared for application by pouring off surface liquid. To test the effect of compost tea depth, compost tea was siphoned from $15-\mathrm{cm}$ depth. All NCT were filtered using eight layers of cheesecloth to prevent clogging of the spray nozzles of the hand pump applicators.

Aerated compost tea production. ACT was produced with two types of commercial units designed for this purpose. Compost Tea Brewers (Growing Solutions, Inc., Sonoma, CA) were filled with 50 liters of tap water and run for $2 \mathrm{~h}$ for chlorine reduction according to manufacturer's directions. If used, nutrient additives (described above) were mixed into the water prior to the addition of compost. Compost (4.5 liters, contained in a mesh basket) was suspended in the water. After 34 to $36 \mathrm{~h}$, ACT was removed through a valve and used for application.

ACT was also produced with a Bioblender (Soil Soup). Fifteen liters of tap water was placed in a 19-liter bucket and aerated for $2 \mathrm{~h}$ for chlorine reduction according manufacturer's directions. When indicated, nutrient additives were mixed into the water (described above). Compost (500 g; approximately 25:1 water:compost, $\mathrm{vol} / \mathrm{vol}$ ) was then immersed in the water in a $100-\mu m$ mesh filter bag (Soil Soup). To assist the removal of soluble material and microorganisms from the compost, the filter bag was lifted above the water and allowed to drain into the bucket for $15 \mathrm{~s}$, then re-immersed for $30 \mathrm{~s}$. This was done three times, with the filter bag left in the liquid for the remainder of the 34- to 36-h production cycle. For ACT, no additional filtration was needed prior to application.

Botrytis disease assay. $B$. cinerea inoculum was produced by individually culturing four isolates of $B$. cinerea for 2 weeks on potato dextrose agar (Difco). Isolates were from blackberry, strawberry, geranium, and impatiens. Plates were flooded with sterile distilled water and gently rubbed with a sterile, bent glass rod to release conidia. The spore suspensions were decanted through four layers of cheesecloth to remove mycelial fragments. The suspensions were combined and spore concentration was determined using a hemacytometer. The conidial suspension was diluted with sterile distilled water to $1 \times 10^{5}$ conidia/ml, and then immediately applied to geranium leaves using an aerosol spray bottle (Nalgene Inc., Rochester, NY).

Compost tea treatments were assessed using an assay developed for screening biological control agents on geranium (21). Six- to 8-week-old greenhouse-grown geranium seedlings ('Ringo Red 2000') with five to seven fully expanded leaves were used. Cotyledons and all nonexpanded leaves were removed before treatment. The adaxial leaf surfaces of all leaves were sprayed until runoff with an aerosol spray bottle (Nalgene Nunc International, Rochester, NY) and then dusted with dried, ground geranium leaves (approximately $1 \mathrm{mg} / \mathrm{cm}^{2}$ ). The leaf powder simulated dropped flower petals, necrotic tissue, and other exogenous sources of nutrient and increased the potential for $B$. cinerea infection. Treated plants were placed in a growth chamber for $24 \mathrm{~h}$ $\left(22^{\circ} \mathrm{C}\right.$, 16-h photoperiod, ambient humidity) then inoculated with $B$. cinerea spore suspension (described above) by misting the adaxial leaf surfaces using a hand pump sprayer. Plants were placed in a randomized block design and then incubated at $22^{\circ} \mathrm{C}$ with $>85 \%$ humidity for 5 to 7 days in a growth chamber (16-h photoperiod). Disease level was assessed using a 4-point scale: $0=$ no lesions; $1=$ discreet lesions occupying less than one-third of the leaf area; 2 = spreading lesions occupying one-third to two-thirds of the leaf area; and $3=$ greater than two-thirds of the leaf area covered in lesions.
Addition of spray adjuvants to aerated compost tea. Because the production time for ACT was short, it was used as the experimental model for adding spray adjuvants shown to be effective in enhancing the disease suppressive activity of commercial biological control agents (22). The following adjuvants were added to specified compost tea treatments prior to application: Gum Karaya ( $0.05 \%$ wt/vol, Sigma Chemical Co., St. Louis, MO); Thermx-70 Yucca Extract $(0.05 \%$ vol/vol, Cellu-con, Inc., Strathmore, CA); Nu Film 17 Spreader/Sticker $(0.1 \% \quad \mathrm{vol} / \mathrm{vol}, \quad$ Miller Chemical \& Fertilizer Company, Hanover, PA); and Latron B1956 Spreader/Sticker ( $0.1 \%$ vol/vol, Rohm \& Haas Co., Philadelphia, PA). Treatments consisted of compost teas mixed with one of the above adjuvants or Tween $20(0.001 \% \mathrm{vol} / \mathrm{vol}$, Fisher Scientific, Fairhaven, NJ), the adjuvants alone mixed with water, and noninoculated and Botrytis-inoculated control. All treatments were applied using a hand pump as described above.

Bacterial populations in aerated compost tea. Culturable bacterial populations were enumerated to monitor the effects of population changes on disease suppression. A 1-ml sample of compost tea was aseptically removed from each compost tea production unit before application. After serial dilution in sterile $0.02 \mathrm{M}$ potassium phosphate buffer ( $\mathrm{pH} 7.0$ ), $50 \mu \mathrm{l}$ of a dilution was plated using an automated spiral plater (Eddy Jet, IUL Instruments, Barcelona, Spain) on 5\% trypticase soy broth agar (1.5 g/liter Difco trypticase soy broth with $15 \mathrm{~g} / \mathrm{liter}$ agar and $100 \mu \mathrm{g} / \mathrm{ml}$ cycloheximide) for bacteria and water agar $\mathrm{pH} 6$ (18 g/liter agar with $50 \mu \mathrm{g} / \mathrm{ml}$ rifampicin) for fungi. Plates were incubated at $22^{\circ} \mathrm{C}$ for 3 and 7 days for bacteria and fungi, respectively. Colonies were enumerated and converted to $\log \mathrm{CFU} / \mathrm{ml}$.

Experimental design and statistical analysis. Each experiment had two or three control treatments that did not receive compost tea applications: (i) noninoculated control $=$ plants sprayed with water and dusted with geranium leaf powder; (ii) Botrytis control = plants sprayed with water and dusted with geranium leaf powder $24 \mathrm{~h}$ prior to being inoculated with $B$. cinerea as described; and (iii) biological positive control $=$ plants sprayed with an approximately $1 \times 10^{9} \mathrm{CFU} / \mathrm{ml}$ suspension of Burkholderia ambifraria AMMDR1 (19), a 48-h yeast extract broth (13.3 g/liter nutrient broth (Difco), $1.0 \mathrm{~g} /$ liter Bacto yeast extract (Difco), $5.0 \mathrm{~g} /$ liter sucrose, $0.24 \mathrm{~g} /$ liter anhydrous $\mathrm{MgSO}_{4}$, and $\mathrm{pH}$ adjusted to 7.2 with $1 \mathrm{M} \mathrm{KOH}$ ) culture diluted in $0.02 \mathrm{M}$ potassium phosphate buffer $(\mathrm{pH} 7.0)$ and dusted with geranium leaf powder $24 \mathrm{~h}$ prior to inoculation with Botrytis spore suspension. The AMMDR1 treatment was used as a biological control standard early in the investigations. Experiments consisted of these three controls 
plus the different compost tea batches being tested. Due to space constraints, the noninoculated control or biological positive control treatments were sometimes omitted. All experiments were factorials of various combinations of compost class, aeration, nutrient additions, or adjuvants, arranged in randomized complete blocks with six to eight replications (individual plants). The individual leaf ratings (described above) were averaged for the entire plant to create a plant disease rating. This plant disease rating was used for statistical analysis. For each experiment, plant disease ratings were tested for variance normality then subjected to variance analysis using preplanned linear contrasts of treatment means separated by Fisher's protected least significant difference using PROC MIXED in SAS version 8.1 (SAS Institute Inc., Cary, NC). The bacterial populations in specified categories of compost tea were compared using nonpaired $t$ tests after $\log _{10}$ transformation to correct for nonnormal variance between compost tea categories. Chi-square analysis was used to compare the frequency of NCT batches that significantly suppressed disease made from different compost sources.

\section{RESULTS}

NCT production factors. Compost class influenced the frequency of disease suppression (Table 2). Differences across compost samples were evident when NCTs were produced without nutrient additives and applied as 7-day-old compost teas. Twenty-seven compost samples were used to make 104 NCT batches from both undigested plant material and manure-based composts, with only $31 \%$ of the batches significantly $(P<0.05)$ reducing disease levels (Table 2). However, specific compost samples had much greater disease reduction associated with them. NCT produced from either a chicken manure compost or a yard trimmings compost (compost samples 4 and 26, respectively; Table 1) significantly reduced disease $(P<0.05)$ more than $50 \%$ of the time (Table 3 ). In total, 24 of 49 batches of NCT made from compost samples in these two compost classes and originating from the same the production facility (compost samples 5 to 8 and 26 to 29), significantly reduced disease $(P<0.05)$ (Table 3$)$. Only eight of the 55 NCT batches produced with the 20 other compost samples significantly reduced disease $(P<0.05)$. Chi-square analysis indicated that NCT made from the yard trimmings composts and chicken manure composts (Table 2) had a significantly greater frequency $(P<0.001)$ of disease suppression than NCT made from all other compost classes.

The duration of NCT production appeared to influence disease suppression. Increasing the production time from 7 to 14 days produced NCTs that significantly

Table 2. Effect of compost class used to make nonaerated compost teas ${ }^{\mathrm{y}}$ (NCT) on suppression of gray mold disease of geraniums inoculated with Botrytis cinerea

\begin{tabular}{lccc}
\hline Compost class & $\begin{array}{c}\text { No. of compost } \\
\text { samples in each type }\end{array}$ & $\begin{array}{c}\text { Total no. of NCT } \\
\text { batches }\end{array}$ & $\begin{array}{c}\text { No. of batches that significantly } \\
\text { suppressed disease }\end{array}$ \\
\hline Yard trimmings & 8 & 30 & 11 \\
Chicken & 7 & 35 & 16 \\
Dairy & 2 & 10 & 2 \\
CMC & 2 & 3 & 1 \\
Micronized & 1 & 2 & 0 \\
Mint blend & 1 & 5 & 1 \\
Steer blend & 2 & 7 & 1 \\
Bark & 2 & 5 & 0 \\
Vermicompost & 2 & 7 & 32 \\
Sum & 27 & 104 & 0 \\
\hline
\end{tabular}

y Compost and water $(5: 1 \mathrm{vol} / \mathrm{vol})$ held in an open container for 7 days.

${ }^{\mathrm{z}}$ Significantly different $(P<0.05)$ from the $B$. cinerea-inoculated control as determined by single degree of freedom linear contrast.
$(P<0.1)$ reduced disease in $29 \%$ of the direct comparisons. Disease suppression of 7-day-old NCT was never significantly greater $(P<0.1)$ than 14-day-old NCT (Table 4).

Significant differences $(P<0.05)$ in disease reduction were not detected between NCT removed from a depth of $15 \mathrm{~cm}$ and that removed from the surface for all NCT produced with compost that contained manure (compost samples 9, 12, 16, Table 1). In five of seven experiments, only NCT removed from the surface significantly reduced disease $(P<0.05)$ compared with the Botrytis control treatment (data not shown).

Adding nutrients to NCT during production generally did not influence disease suppression in 31 batches produced with several composts and nutrient additives. Only 10 and $25 \%$ of the NCT made with and without nutrient additives, respectively, significantly $(P<0.05)$ reduced disease compared with the Botrytisinoculated control (data not shown). NCT with nutrient additives significantly $(P<$ 0.03 ) increased disease in three experiments and significantly decreased disease in one experiment (data not shown).

Similarly, stirring of NCT during production significantly $(P=0.005)$ increased disease compared with nonstirred NCT in one of 18 experiments (data not shown). In these 18 experiments, $50 \%$ of the nonstirred NCT batches significantly $(P<$ $0.05)$ decreased disease development compared with the Botrytis control, while stirred NCT batches resulted in significant disease reduction $33 \%$ of the time (data not shown).

Impact of aerating compost tea on disease suppression. There was no significant difference $(P>0.05)$ in disease ratings for $85 \%$ of the linear contrasts comparing ACT and NCT that were produced with a range of compost sources and nutrient additives (Table 5). When significant differences $(P<0.05)$ were detected, $75 \%$ indicated that treatments with NCT had less disease than ACT.

Effect of nutrient additives on bacterial population and disease suppression of ACT. ACT made with nutrient additives had significantly greater $(P<0.05)$ bacte-

Table 3. Variability of Botrytis cinerea suppression from applying nonaerated compost teas ${ }^{\mathrm{y}}$ that were made with compost from sequential windrows produced at the same composting facility

\begin{tabular}{|c|c|c|c|c|c|c|c|}
\hline \multicolumn{4}{|c|}{ Chicken manure compost } & \multicolumn{4}{|c|}{ Yard trimmings compost } \\
\hline $\begin{array}{l}\text { Compost } \\
\text { sample }^{\mathrm{z}}\end{array}$ & Sample date & $\begin{array}{l}\text { No. } \\
\text { of batches } \\
\text { tested }\end{array}$ & $\begin{array}{l}\text { No. of batches } \\
\text { with disease } \\
\text { suppression }\end{array}$ & $\begin{array}{l}\text { Compost } \\
\text { sample }^{\mathrm{z}}\end{array}$ & Sample date & $\begin{array}{l}\text { No. } \\
\text { of batches } \\
\text { tested }\end{array}$ & $\begin{array}{l}\text { No. of batches } \\
\text { with disease } \\
\text { suppression }\end{array}$ \\
\hline 4 & $12 / 16 / 1998$ & 9 & 5 & 25 & $10 / 21 / 1998$ & 3 & 0 \\
\hline 5 & 2/16/1999 & 5 & 2 & 26 & $12 / 16 / 1998$ & 9 & 6 \\
\hline 6 & $2 / 16 / 1999$ & 10 & 4 & 27 & 2/16/1999 & 6 & 2 \\
\hline 7 & 4/19/1999 & 2 & 2 & 28 & $4 / 19 / 1999$ & 2 & 1 \\
\hline 8 & $5 / 26 / 1999$ & 2 & 1 & 29 & $5 / 25 / 1999$ & 1 & 1 \\
\hline Sum & & 28 & 14 & Sum & & 21 & 10 \\
\hline
\end{tabular}

${ }^{y}$ Compost and water (5:1 vol/vol) held in an open container for 7 days.

${ }^{\mathrm{z}}$ Compost samples characterized in Table 1. 
rial populations than ACT made without nutrients (Table 6). While culturable bacterial populations were greater, linear contrast analysis indicated that ACT made with nutrient additives significantly $(P<$ 0.05 ) reduced disease in only $4 \%$ of the direct comparisons to ACT made without nutrient additives (Table 6). Therefore, simply increasing the population of culturable bacteria was not correlated with the reduction of gray mold under the experimental conditions.

Influence of spray adjuvants. Adding spray adjuvants to ACT produced with or without nutrient additives significantly $(P$ $<0.05)$ reduced disease levels compared with applying either the ACT or adjuvants alone (Table 7).

\section{DISCUSSION}

The high degree of variability in gray mold suppression from NCT and ACT applications indicates that it would be difficult to achieve commercially acceptable disease control regardless of the production parameters used. There were no consistent benefits to aerating, adding nutrients, or other commonly practiced production methods. This finding is contrary to many popular press reports (1113), which state that the use of aeration and nutrient amendments enhances disease control, but is strongly supported by the few studies that have directly compared ACT to NCT using the same compost sample $(1,9,29,31)$. It should be noted that compost tea applications did offer some disease control and could be better than nothing if production constraints (e.g., organic production) make other control methods unavailable.

There are many claims and counter claims regarding the influence of aeration on disease control afforded by compost tea applications $(6,11-13)$. The data presented here and from the few investigations that have directly compared ACT to NCT using the same compost samples indicate that both methods appear to offer similar disease suppression (1,9,29,31). Scheuerell and Mahaffee compared ACT to NCT production methods for control of Pythium damping-off of cucumber (31) and powdery mildew, rust, and blackspot of rose (28), and found no differences in disease control. These results were in agreement with Al-Dahmani et al. (1), where no dif- ferences in control of bacterial spot of tomato between ACT and NCT were observed. However, NCT was found to inhibit germination of Venturia inaequalis conidia while the aerated compost tea did not (9). These results appear to indicate

Table 5. Comparing nonaerated and aerated compost teas made with or without nutrient additives on suppression of gray mold disease of geraniums inoculated with Botrytis cinerea

\begin{tabular}{|c|c|c|c|c|c|c|}
\hline \multirow[b]{2}{*}{$\begin{array}{l}\text { Compost } \\
\text { sample }^{v}\end{array}$} & \multirow[b]{2}{*}{$\begin{array}{l}\text { Nutrient } \\
\text { additives }^{w}\end{array}$} & \multirow[b]{2}{*}{ Compost class } & \multicolumn{4}{|c|}{ Disease ratingu } \\
\hline & & & $\begin{array}{l}\text { Inoculated } \\
\text { control }\end{array}$ & $\begin{array}{c}\text { Noninoculated } \\
\text { control }\end{array}$ & $\mathbf{N C T}^{\mathbf{x}}$ & $\mathbf{A C T} \mathbf{T}^{\mathbf{y}}$ \\
\hline 3 & None & Blend & $1.96 \mathrm{a}^{\mathrm{z}}$ & $1.74 \mathrm{ab}$ & $1.51 \mathrm{~b}$ & $1.50 \mathrm{~b}$ \\
\hline 3 & None & Blend & $1.78 \mathrm{a}$ & $1.89 \mathrm{a}$ & $1.86 \mathrm{a}$ & $2.13 b$ \\
\hline 21 & None & Vermicompost & $2.20 \mathrm{a}$ & $0.89 \mathrm{c}$ & $1.63 \mathrm{~b}$ & $2.10 \mathrm{a}$ \\
\hline 21 & None & Vermicompost & $2.03 \mathrm{a}$ & $0.69 \mathrm{~b}$ & $1.99 \mathrm{a}$ & $1.71 \mathrm{a}$ \\
\hline 29 & None & Yard trimmings & $2.23 \mathrm{a}$ & $0.2 \mathrm{~b}$ & $2.18 \mathrm{a}$ & $1.98 \mathrm{a}$ \\
\hline 29 & None & Yard trimmings & $1.77 \mathrm{a}$ & $0.91 \mathrm{~b}$ & $1.99 \mathrm{a}$ & $1.49 \mathrm{a}$ \\
\hline 3 & Bacterial & Blend & $1.96 \mathrm{a}$ & $1.74 \mathrm{a}$ & $1.64 \mathrm{ab}$ & $1.40 \mathrm{~b}$ \\
\hline 3 & Bacterial & Blend & $1.78 \mathrm{a}$ & $1.89 \mathrm{a}$ & $1.95 \mathrm{a}$ & $1.89 \mathrm{a}$ \\
\hline 21 & Bacterial & Vermicompost & $2.20 \mathrm{a}$ & $0.89 \mathrm{~b}$ & $1.83 \mathrm{a}$ & $1.83 \mathrm{a}$ \\
\hline 21 & Bacterial & Vermicompost & $2.03 \mathrm{a}$ & $0.69 \mathrm{~b}$ & $1.83 \mathrm{a}$ & $1.79 \mathrm{a}$ \\
\hline 29 & Bacterial & Yard trimmings & $2.23 \mathrm{a}$ & $0.2 \mathrm{c}$ & $2.34 \mathrm{a}$ & $1.90 \mathrm{~b}$ \\
\hline 29 & Bacterial & Yard trimmings & $1.77 \mathrm{a}$ & $0.91 \mathrm{~b}$ & $1.72 \mathrm{a}$ & $1.73 \mathrm{a}$ \\
\hline 3 & Fungal & Blend & $1.96 \mathrm{a}$ & $1.74 \mathrm{ab}$ & $1.48 \mathrm{~b}$ & $1.18 \mathrm{bc}$ \\
\hline 3 & Fungal & Blend & $1.78 \mathrm{a}$ & $1.89 \mathrm{a}$ & $1.82 \mathrm{a}$ & $1.78 \mathrm{a}$ \\
\hline 21 & Fungal & Vermicompost & $2.20 \mathrm{a}$ & $0.89 \mathrm{c}$ & $1.83 \mathrm{ab}$ & $1.74 \mathrm{~b}$ \\
\hline 21 & Fungal & Vermicompost & $2.03 \mathrm{a}$ & $0.69 \mathrm{c}$ & $1.74 \mathrm{~b}$ & $1.35 \mathrm{~b}$ \\
\hline 29 & Fungal & Yard trimmings & $2.23 \mathrm{a}$ & $0.2 \mathrm{~b}$ & $2.13 \mathrm{a}$ & $2.12 \mathrm{a}$ \\
\hline 29 & Fungal & Yard trimmings & $1.77 \mathrm{a}$ & $0.91 \mathrm{~b}$ & $1.66 \mathrm{a}$ & $1.57 \mathrm{a}$ \\
\hline 8 & Molasses & Chicken & $1.52 \mathrm{a}$ & $0.52 \mathrm{~d}$ & $1.17 \mathrm{c}$ & $1.94 \mathrm{~b}$ \\
\hline 8 & Molasses & Chicken & $2.43 \mathrm{a}$ & $0.34 \mathrm{~b}$ & $2.23 \mathrm{a}$ & $2.17 \mathrm{a}$ \\
\hline 8 & Molasses & Chicken & $1.71 \mathrm{a}$ & $0.16 \mathrm{~b}$ & $1.73 \mathrm{a}$ & $1.95 \mathrm{a}$ \\
\hline 13 & Molasses & CMC & $1.87 \mathrm{a}$ & $0.37 \mathrm{c}$ & $1.08 \mathrm{~b}$ & $1.35 \mathrm{ab}$ \\
\hline 13 & Molasses & $\mathrm{CMC}$ & $2.67 \mathrm{a}$ & $0.4 \mathrm{~b}$ & $2.60 \mathrm{a}$ & $2.42 \mathrm{a}$ \\
\hline 13 & Molasses & $\mathrm{CMC}$ & $2.18 \mathrm{a}$ & $0.98 \mathrm{~d}$ & $1.47 \mathrm{~cd}$ & $1.90 \mathrm{bc}$ \\
\hline 29 & Molasses & Yard trimmings & $1.52 \mathrm{a}$ & $0.57 \mathrm{c}$ & $0.96 \mathrm{~b}$ & $1.46 \mathrm{a}$ \\
\hline 29 & Molasses & Yard trimmings & $2.18 \mathrm{a}$ & $0.98 \mathrm{~b}$ & $2.20 \mathrm{a}$ & $2.35 \mathrm{a}$ \\
\hline 29 & Molasses & Yard trimmings & $1.71 \mathrm{a}$ & $0.16 \mathrm{~b}$ & $1.69 \mathrm{a}$ & $1.95 \mathrm{a}$ \\
\hline
\end{tabular}

u Plant disease rating was determined by rating each leaf then averaging the ratings from a plant. Each leaf was rated using a 0 to 3 point scale, where $0=$ no lesions and $3=$ more than two-thirds of the leaf area covered in lesions.

v Compost samples characterized in Table 1.

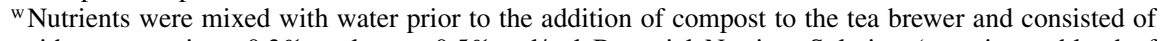
either no nutrient, $0.3 \%$ molasses, $0.5 \%$ vol/vol Bacterial Nutrient Solution (proprietary blend of molasses, kelp, and trace materials), or fungal nutrient mixture (powdered soluble kelp, liquid humic acids, and rock dust).

${ }^{x}$ NCT (nonaerated compost tea) held for 7 days in an open 19-liter bucket with 2 liters of compost, 10 liters of water, and the listed nutrient additives.

y ACT (aerated compost tea) made with none, bacterial, or fungal nutrients, and aerated for $36 \mathrm{~h}$ with a Bio-blender (Soil Soup, Inc., Edmonds, WA). ACT made with molasses was aerated with a Compost Tea Brewer (Growing Solutions, Inc., Eugene, OR).

${ }^{\mathrm{z}}$ Within a row, numbers followed by the same letter are not significantly different $(P<0.05)$ according to Fisher's protected LSD.

Table 4. Effect of applying 7- or 14-day-old nonaerated compost tea ${ }^{\mathrm{v}}$ on suppression of gray mold disease of geraniums inoculated with Botrytis cinerea

\begin{tabular}{|c|c|c|c|c|c|c|c|c|}
\hline \multirow[b]{3}{*}{$\begin{array}{l}\text { Compost } \\
\text { sample }^{w}\end{array}$} & \multirow[b]{3}{*}{ Compost class } & \multirow[b]{3}{*}{$\begin{array}{l}\text { Noninoculated } \\
\text { control }^{x}\end{array}$} & \multirow[b]{3}{*}{$\begin{array}{l}\text { Botrytis } \\
\text { control }^{x}\end{array}$} & \multicolumn{4}{|c|}{ Duration of fermentation } & \multirow[b]{3}{*}{ AMMDR1 ${ }^{z}$} \\
\hline & & & & \multicolumn{2}{|c|}{7 days } & \multicolumn{2}{|c|}{14 days } & \\
\hline & & & & $\begin{array}{l}\text { Disease } \\
\text { rating }^{x}\end{array}$ & $\begin{array}{l}\text { Proportion } \\
\text { of suppressive } \\
\text { bioassays }^{\mathrm{y}}\end{array}$ & $\begin{array}{l}\text { Disease } \\
\text { rating }^{x}\end{array}$ & $\begin{array}{c}\text { Proportion } \\
\text { of suppressive } \\
\text { bioassays }^{y}\end{array}$ & \\
\hline 4 & Chicken & $0.43 \pm 0.11$ & $1.50 \pm 0.28$ & $1.16 \pm 0.30$ & $1 / 3$ & $1.20 \pm 0.36$ & $2 / 3$ & $0.15 \pm 0.09$ \\
\hline 5 & Chicken & $0.36 \pm 0.04$ & $1.67 \pm 0.28$ & $1.36 \pm 0.37$ & $1 / 4$ & $1.14 \pm 0.12$ & $3 / 4$ & $0.16 \pm 0.05$ \\
\hline 6 & Chicken & $0.39 \pm 0.02$ & $1.70 \pm 0.32$ & $1.41 \pm 0.54$ & $1 / 4$ & $1.29 \pm 0.24$ & $1 / 4$ & $0.14 \pm 0.09$ \\
\hline 26 & Yard trimmings & $0.21 \pm 0.13$ & $1.68 \pm 0.46$ & $1.23 \pm 0.31$ & $3 / 3$ & $1.21 \pm 0.21$ & $2 / 3$ & $0.14 \pm 0.08$ \\
\hline 27 & Yard trimmings & $0.36 \pm 0.07$ & $1.60 \pm 0.46$ & $1.39 \pm 0.26$ & $1 / 3$ & $1.31 \pm 0.19$ & $1 / 3$ & $0.13 \pm 0.09$ \\
\hline
\end{tabular}

v Compost and water (5:1 vol/vol) held in an open container for 7 to 14 days without disturbance.

${ }^{\mathrm{w}}$ Compost samples characterized in Table 1.

${ }^{\mathrm{x}}$ Mean disease rating over bioassays \pm standard deviation. Treatments were applied to six replicate plants.

y Proportion of significantly suppressive bioassays of total bioassays (significantly greater than disease rating for Botrytis-inoculated control according to linear contrasts, $P=0.05$; determined separately for each bioassay).

${ }^{\mathrm{z}}$ Disease rating for plants sprayed with an approximately $1 \times 10^{9} \mathrm{CFU} / \mathrm{ml}$ suspension of Burkholderia ambifraria AMMDR1. 
that aeration does not increase disease control; thus, the factors influencing the choice of compost tea production methods are likely to depend on whether either time or cost of tea production equipment is a bigger constraint to using compost teas.

In general, disease suppression associated with compost tea applications appeared to be related to a particular compost sample and marginally related to a compost class. It is not clear how these results relate to prior research, since there is no indication that multiple samples of the same compost class were investigated. However, the results presented here agree with prior reports of compost classes composed of manures $(2,10,37,38)$ and undigested plant material $(10,29,31)$ appearing to be more suitable for producing disease suppressive compost teas than other classes of compost. These data indicate that there is still a need to further investigate the role of compost class on the production of diseasesuppressive compost teas.

Increasing NCT production time from 7 to 14 days often resulted in significant disease suppression, which is similar to results of prior investigations where disease suppression was shown to increase with fermentation time to a maximum of 14 days and then decline $(16,18,37)$. The effect of fermentation time on disease suppression of ACT applications has not been investigated. However, there is anecdotal evidence indicating that fermentation times of 7 to 14 days are needed for effective disease suppression using ACT (7). With both NCT and ACT, suppressed disease with increased fermentation time could be due to accumulation of antibiotics or other secondary metabolites produced by the microbes (9). It is not clear whether the disease suppression associated with compost tea applications is a result of the secondary metabolites produced during fermentation or the colonization of and subsequent interactions on the leaf surface by the microbes reproducing during fermentation. It is also possible that differences in the microbial community structure among tea batches could impact disease suppression.
The addition of nutrients is routinely recommended to enhance disease suppression of ACT (11-13). However, in this study using two different brewers, the production of compost teas produced with nutrient additives did not significantly reduced disease compared with compost teas without added nutrients in a large majority of the direct comparisons, although bacterial populations in the ACT were significantly increased with nutrients. This is in agreement with other research (31) where total bacteria, active bacteria (measured through direct cell counts), as well as culturable populations were not directly related to disease suppression when all types of nutrient additives were considered. It is possible that residual nutrients from the additives intended to encourage microbial reproduction in the compost tea could support saprophytic growth of the pathogen and counteract biological control. This was observed in the suppression of Pythium root rot, where residual molasses in compost tea negated otherwise consistent biological control

Table 6. The effect of producing aerated compost tea $(\mathrm{ACT})^{\mathrm{v}}$ with or without nutrient additives on tea bacteria populations and suppression of gray mold of geraniums inoculated with Botrytis cinerea

\begin{tabular}{|c|c|c|c|c|c|c|c|}
\hline \multirow{2}{*}{$\begin{array}{l}\text { Compost tea } \\
\text { nutrient } \\
\text { additive }^{\mathrm{z}}\end{array}$} & \multicolumn{3}{|c|}{ Disease rating $^{\mathrm{w}}$} & \multicolumn{2}{|c|}{$\begin{array}{c}\text { Proportion of suppressive } \\
\text { bioassays }^{\mathrm{x}}\end{array}$} & \multicolumn{2}{|c|}{$\begin{array}{l}\text { Bacteria population } \\
\quad\left(\log _{10} \mathrm{CFU} / \mathrm{ml}\right)^{\mathrm{y}}\end{array}$} \\
\hline & control & No nutrient & Nutrient & No nutrient & Nutrient & No nutrient & Nutrient \\
\hline Bacterial & $2.00 \pm 0.20$ & $1.82 \pm 0.30$ & $1.76 \pm 0.19$ & $1 / 6$ & $2 / 6$ & $5.93 \pm 0.20$ & $8.28 \pm 0.55$ \\
\hline Fungal & $1.99 \pm 0.37$ & $1.81 \pm 0.31$ & $1.69 \pm 0.31$ & $1 / 6$ & $4 / 6$ & $5.93 \pm 0.20$ & $7.66 \pm 0.27$ \\
\hline Molasses & $1.89 \pm 0.42$ & $1.79 \pm 0.35$ & $1.83 \pm 0.26$ & $0 / 10$ & $1 / 8$ & $6.47 \pm 0.66$ & $8.32 \pm 0.43$ \\
\hline Yeast powder & $2.44 \pm 0.43$ & $2.34 \pm 0.38$ & $2.50 \pm 0.26$ & $0 / 6$ & $0 / 6$ & $7.09 \pm 0.89$ & $8.27 \pm 0.56$ \\
\hline
\end{tabular}

${ }^{\mathrm{v}}$ ACT made with none, bacterial, or fungal nutrients was aerated for $36 \mathrm{~h}$ with a Bio-blender (Soil Soup, Inc., Edmonds, WA). ACT made with molasses or yeast was aerated with a Compost Tea Brewer (Growing Solutions, Inc., Eugene, OR).

${ }^{w}$ Mean disease rating over bioassays \pm standard deviation. Treatments were applied to six replicate plants.

${ }^{\mathrm{x}}$ Proportion of significantly suppressive bioassays of total bioassays (significantly greater than disease rating for botrytis inoculated control according to linear contrasts, $P=0.05$; determined separately for each bioassay).

y Bacterial populations $\log _{10} \mathrm{CFU} / \mathrm{ml}$ compost tea, enumerated on $5 \% \mathrm{TSBA} \pm$ standard deviation.

${ }^{\mathrm{z}}$ Nutrients were mixed with water prior to the addition of compost to the tea brewer and consisted of either no nutrient, $0.3 \%$ molasses, $0.3 \%$ hydrolyzed yeast powder, $0.5 \% \mathrm{vol} / \mathrm{vol}$ Bacterial Nutrient Solution (proprietary blend of molasses, kelp, and trace materials), or fungal nutrient mixture (powdered soluble kelp, liquid humic acids, and rock dust).

Table 7. Enhancement of disease suppression by mixing adjuvants with aerated compost teas (ACT) prior to application

\begin{tabular}{|c|c|c|c|c|c|c|c|}
\hline \multirow[b]{2}{*}{$\begin{array}{l}\text { Compost } \\
\text { samplew }^{w}\end{array}$} & \multirow[b]{2}{*}{$\begin{array}{l}\text { Nutrient } \\
\text { additives }^{x}\end{array}$} & \multirow[b]{2}{*}{ Adjuvant added to ACT $^{y}$} & \multicolumn{5}{|c|}{ Disease severity $^{\mathrm{v}}$ (\%leaf area) } \\
\hline & & & $\begin{array}{c}\text { Noninoculated } \\
\text { control }\end{array}$ & $\begin{array}{c}\text { ACT + } \\
\text { adjuvants }\end{array}$ & ACT & Adjuvants & $\begin{array}{c}\text { Inoculated } \\
\text { control }\end{array}$ \\
\hline 2 & None & Nu-Film 17 (0.1\% vol/vol) & nd & $2.29 \mathrm{a}^{\mathrm{z}}$ & $2.72 \mathrm{~b}$ & $2.81 \mathrm{~b}$ & $2.67 \mathrm{~b}$ \\
\hline 2 & None & Nu-Film 17 (0.1\% vol/vol) & $1.64 \mathrm{a}$ & $2.00 \mathrm{~b}$ & $2.68 \mathrm{~cd}$ & $2.75 \mathrm{~d}$ & $2.63 \mathrm{c}$ \\
\hline 2 & Yeast & Nu-Film $17(0.1 \%$ vol/vol $)$ & $1.46 \mathrm{a}$ & $1.97 \mathrm{~b}$ & $2.82 \mathrm{e}$ & $2.75 \mathrm{de}$ & $2.63 \mathrm{c}$ \\
\hline 7 & Fungal & $\begin{array}{l}\text { Karaya gum }(0.05 \% \mathrm{wt} / \mathrm{vol})+ \\
\text { ThermX } 70(0.05 \% \mathrm{vol} / \mathrm{vol})\end{array}$ & $1.32 \mathrm{a}$ & $1.87 \mathrm{~b}$ & $2.22 \mathrm{c}$ & $2.13 \mathrm{c}$ & $2.24 \mathrm{c}$ \\
\hline 20 & Molasses & Latron B1956 (0.1\% vol/vol) & $1.39 \mathrm{a}$ & $1.96 \mathrm{~b}$ & $2.42 \mathrm{c}$ & $2.49 \mathrm{c}$ & $2.51 \mathrm{c}$ \\
\hline 21 & Bacterial & $\begin{array}{c}\text { Karaya gum }(0.05 \% \mathrm{wt} / \mathrm{vol})+ \\
\text { ThermX } 70(0.05 \% \mathrm{vol} / \mathrm{vol})\end{array}$ & $0.69 \mathrm{a}$ & $1.05 \mathrm{a}$ & $1.79 \mathrm{~b}$ & $2.08 \mathrm{c}$ & $2.03 \mathrm{c}$ \\
\hline
\end{tabular}

\footnotetext{
${ }^{\mathrm{v}}$ Plant disease severity of gray mold disease of geraniums inoculated with Botrytis cinerea was determined by averaging the percentage of infected leaf tissue for each leaf on the plant.

${ }^{\mathrm{w}}$ Compost samples characterized in Table 1.

${ }^{x}$ Nutrient additives consisted of either no additives, $0.3 \%$ molasses, $0.3 \%$ hydrolyzed yeast powder, $0.5 \%$ vol/vol Bacterial Nutrient Solution (proprietary blend of molasses, kelp, and trace materials) or fungal nutrient mixture (powdered soluble kelp, liquid humic acids, and rock dust). ACT aerated for $36 \mathrm{~h}$ with a Bio-blender (Soil Soup, Inc., Edmonds, WA).

y Adjuvants added to sprayer just prior to application.

${ }^{\mathrm{z}}$ Within a row, numbers followed by the same letter are not significantly different $(P<0.05)$ according to Fisher's protected LSD. Plant disease rating was determined by rating each leaf then averaging the ratings from a plant. Each leaf was rated using a 0 to 3 point scale, where $0=$ no lesions; $1=$ discreet lesions occupying less than one-third of the leaf area; 2 = spreading lesions occupying one-third to two-thirds of the leaf area; $3=$ more than two-thirds of the leaf area covered in lesions. $n d=$ treatment not present in this experiment.
} 
(31). Another reason to approach the use of nutrient additives in compost tea with caution is the concern that nutrient additives could support the growth of bacterial human pathogens if contaminated compost was used inadvertently (3).

The use of adjuvants is a common practice in chemical pesticide formulation and application (4), but it has received little attention in the biological control literature. The data presented here indicate that adjuvants that increase dispersal and adherence of spray droplets on leaf surfaces increase disease control. Similarly, gum karaya and other polysaccharides tankmixed $(0.1 \% \mathrm{vol} / \mathrm{vol})$ with microbial biocontrol agents (BCA) were demonstrated to significantly reduce gray mold of geranium compared with BCA alone and adjuvant controls (22). They have also been shown to restore activity of a biofilm deficient mutant of a foliar biocontrol agent of B. cinerea on geranium (26).

Increased disease suppression of compost tea amended with adjuvants could be due to increased attachment and subsequent survival of applied organisms in a modified phylloplane environment. Modifying the phylloplane environment has been shown to affect the recovery of microorganisms applied in compost tea (27). Microbial epiphyte populations recovered from plants sprayed with various NCTs were significantly reduced when the plants were maintained in a growth chamber at 50 to $60 \%$ relative humidity compared with 90 to $95 \%$ relative humidity (27). Similarly, in our experiments, plants treated with compost tea dried completely in the 24-h period between compost tea application and pathogen inoculation. This change in environment likely limited epiphytic microbial colonization and survival. Preliminary examination with scanning electron microscopy indicated that spray adjuvants greatly increased microbial colonization of geranium leaves from compost tea (S. J. Scheuerell, unpublished). Increased populations of bacterial epiphytes could more effectively compete for phylloplane nutrients and niches, leading to a reduction in $B$. cinerea conidial germination (5).

There is strong interest in both conventional and organic agriculture to develop compost tea production and application practices that positively impact crop productivity and health (3). Compost tea applications can significantly reduce disease caused by $B$. cinerea under environmental conditions that favor disease development; but variability in efficacy from batch to batch of compost tea necessitates further development of a production protocol that consistently reduces disease, even under severe disease pressure. Based on data presented here and Scheuerell and Mahaffee (32), it would appear that future research on the use of compost tea applications for disease control should focus on development of rapid methods for assessing the potential for a compost sample to produce a disease-suppressive compost tea and the use of adjuvants for enhancing compost tea activity. Suppression of seedling damping-off due to Pythium spp. was related to compost maturity and microbial activity as determined using the rapid Solvita compost maturity and respiration kits (32). Methods such as the Solvita kit used to assess microbial activity would be preferable to the analyses used in this study and those used by various commercial laboratories, since they are rapid, provide results within $24 \mathrm{~h}$, and can be employed on-site or before purchase of compost. Similar investigations for methods to assess the suitability of compost for making disease-suppressive compost teas are needed.

It is clear that the use of various adjuvants tank-mixed with compost teas can enhance disease control. Thus, further development of spray adjuvant technology that is compatible with compost teas appears to be a promising direction to minimize variability of disease suppression. A third area of research that is needed is examination of the anecdotal evidence that increasing fermentation time of ACT will result in disease suppression. Cantisano (7) indicates that compost teas produced from short fermentation cycles ( 24 to $36 \mathrm{~h}$ ) have limited utility for disease control and that 7- to 14-day fermentations are needed for consistent disease control.

\section{ACKNOWLEDGMENTS}

Funding from USDA CRIS \# 303-5358-22000024-00D and 303-5358-22000-030-00D and the Oregon association of Nurserymen and Oregon Department of Agriculture made this work possible. Julie DiLeone and Tara Sechler provided valuable technical assistance. Mention of trade names or commercial products in this manuscript is solely for the purpose of providing specific information and does not imply recommendation or endorsement by the U.S. Department of Agriculture.

\section{LITERATURE CITED}

1. Al-Dahmani, J. H., Abbasi, P. A., Miller, S. A., and Hoitink, H. A. J. 2003. Suppression of bacterial spot of tomato with foliar sprays of compost extracts under greenhouse and field conditions. Plant Dis. 87:913-919.

2. Andrews, J. H. 1993. Compost extracts and the biological control of foliar plant disease. Pacific Northwest Pollution Prevention Resource Center Grant Report project \# LNC 91-31, Seattle, WA.

3. Anonymous. 2004. Compost Tea Task Force Final Report. National Organic Standards Board. April 6, 2004. U.S. Dep. Agric. Online publication.

4. Backman, P. A. 1978. Fungicide formulation: Relationship to biological activity. Annu. Rev. Phytopathol. 16:211-237.

5. Blakeman, J. P. 1975. Germination of Botrytis cinerea conidia in vitro in relation to nutrient conditions on leaf surfaces. Trans. Br. Mycol. Soc. 65:239-247.

6. Brinton, W. F., Trankner, A., and Droffner, M. 1996. Investigations into liquid compost extracts. Biocycle 37:68-70.

7. Cantisano, A. 1998. Compost teas. Organic Agricultural Advisors letter, Colfax, CA.
8. Coley-Smith, J. R., Verhoeff, K., and Jarvis, W. R. 1980. The Biology of Botrytis. Academic Press, New York.

9. Cronin, M. J., Yohalem, D. S., Harris, R. F., and Andrews, J. H. 1996. Putative mechanism and dynamics of inhibition of the apple scab pathogen Venturia inaequalis by compost extracts. Soil Biol. Biochem. 28:1241-1249.

10. Elad, Y., and Shtienberg, D. 1994. Effect of compost water extracts on grey mould (Botrytis cinerea). Crop. Prot. 13:109-114.

11. Ingham, E. R. 2000. The Compost Tea Brewing Manual. 2nd ed. Unisun Communications, Corvallis, OR.

12. Ingham, E. R. 2003. The Compost Tea Brewing Manual. 3rd ed. Soil Food Web, Inc., Corvallis, OR.

13. Ingham, E. R., and Alms, M. 1999. Compost Tea Manual 1.1. Soil Food Web, Inc., Corvallis, OR.

14. Jarvis, W. R. 1992. Managing Diseases in Greenhouse Crops. American Phytopathological Society, St. Paul, MN.

15. Johnson, K. B., Sawyer, T. L., and Powelson, M. L. 1994. Frequency of benzimidazole- and dicarboximide-resistant strains of Botrytis cinerea in western Oregon small fruit and snap bean plantings. Plant Dis. 78:572-577.

16. Ketter, N. 1990. Untersuchungen zur Wirkung von Kompost-Extraken auf den Blattbefall der Kartoffel und Tomate durch Phytophthora infestans sowie auf den Befall der Weinrebe durch Plasmopara viticola, Psuedopziza tracheiphila, und Uncinula necator. Ph.D. diss. University of Bonn, Germany.

17. Ketterer, N., Fisher, B., and Weltzien, H. C. 1992. Biological control of Botrytis cinerea on grapevine by compost extracts and their microorganisms in pure culture. Pages 179-186 in: Recent Advances in Botrytis Research. Proc. Int. Botrytis Sympos. 10th. April 5-10 Heraklion, Crete, Greece.

18. Ketterer, N., and Schwager, L. 1992. Effect of compost extracts on the disease incidence and the phyllosphere flora of bush bean and tomato leaves. Meded. Fac. Land. Univ. Gent. 57:411421.

19. King, E. B., and Parke, J. L. 1993. Biocontrol of Aphanomyces root rot and Pythium damping-off by Pseudomonas cepacia AMMD on four pea cultivars. Plant Dis. 77:1185-1188.

20. Levey, M. E., Revell, E. B., Dahm, R., and Machowski, V. 1999. A new surfactant made from kelp seaweed. Roy. Soc. Chem. 230:108116.

21. Mahaffee, W. M., and DiLeone, J. A. 1998. A rapid screening system for biocontrol agents against Botrytis cinerea. (Abstr.) Phytopathology 88:S57.

22. Mahaffee, W., Sechler, T., and Scheuerell, S. 2002. Use of adjuvants to enhance biocontrol efficacy. (Abstr.) Phytopathology 92:S50.

23. McQuilken, M. P., Whipps, J. M., and Lynch, J. M. 1994. Effects of water extracts of composted manure-straw mixture on the plant pathogen Botrytis cinerea. World J. Microbiol. Biotech. 10:20-26.

24. Moyano, C., Gómez, V., and Melgargejo, P. 2004. Resistance to pyrimethanil and other fungicides in Botrytis cinerea populations collected on vegetable crops in Spain. J. Phytopathol. 152:484-490.

25. Riggle, D. 1996. Compost teas in agriculture. Biocycle 37:65-67.

26. Roche, M. M., Mahaffee, W. F., Press, C. M., Sechler, T. M., and Davis, A. L. 2002. Characterization of the biofilm phenotype of Burkolderia sp., FP62 and its role in biocontrol. (Abstr.) Phytopathology 92:S70.

27. Sackenheim, R., Weltzien, H. C., and Kast, W. K. 1994. Effects of microflora composition in the phyllosphere on biological regulation of grapevine fungal diseases. Vitis 33:235-240.

28. Scheuerell, S. J. 2002. Compost teas and 
compost amended container media. Ph.D. diss. Oregon State University, Corvallis.

29. Scheuerell, S. J., and Mahaffee, W. F. 2000. Assessing aerated and non-aerated watery fermented composts and Trichoderma harzianum T-22 for the control of powdery mildew (Sphaerotheca pannosa var. rosae) of rose in the Willamette Valley, Oregon. Phytopathology 90:S69.

30. Scheuerell, S., and Mahaffee, W. 2002. Compost tea: Principles and prospects for plant disease control. Compost Sci. Util. 10:313-338.

31. Scheuerell, S. J., and Mahaffee, W. F. 2004. Compost tea as a container medium drench for suppressing seedling damping-off caused by Pythium ultimum. Phytopathology 94:11561163.

32. Scheuerell, S. J., Sullivan, D. M., and Mahaffee, W. F. 2005. Suppression of seedling damping-off caused by Pythium ultimum, $P$. irregulare, and Rhizoctonia solani in container media amended with a diverse range of Pacific
Northwest compost sources. Phytopathology 95:306-315.

33. Stindt, A. 1990. Untersuchungen zur wirkung und zu den wirkungsmechanismen von Kompostextrakten auf Botrytis cinerea Pers. ex Nocca \& Balb an Erdbeeren, Kopfsalat und Buschbohnen. Ph.D. diss. University of Bonn, Germany.

34. Urban, J., and Tränkner, A. 1993. Control of grey mold (Botrytis cinerea) with fermented compost/water extracts. Pages 8-11 in: Biological control of foliar and post-harvest diseases: Proceedings of a workshop. N. J. Fokkema, J. Kohl, and Y. Elad, eds. Bulletin of the International Organization for Biological and Integrated Control of Noxious Animals and Plants, West Palearctic Regional Section. Vol. 16.

35. Welke, S. E. 2004. The effect of compost extract on the yield of strawberries and the severity of Botyrtis cinerea. J. Sust. Agric. 25:57-68.
36. Weltzien, H. C. 1989. Some effects of composted organic materials on plant health. Agric Ecosyst. Environ. 27:439-446.

37. Weltzien, H. C. 1990. The use of composted materials for leaf disease suppression in field crops. Monogr. Br. Crop Prot. Counc. 45:15120.

38. Weltzien, H. C. 1991. Biocontrol of foliar fungal disease with compost extracts. Pages 430-450 in: Microbial Ecology of Leaves. J. H. Andrews and S. S. Hirano, eds. SpringerVerlag, New York.

39. White, G. C. 1992. The Handbook of Chlorination and Alternative Disinfectants. 3rd ed. Van Nostrand Reinhold, New York.

40. Wu, L., and Ma, L. Q. 2001. Effects of sample storage on biosolids compost stability and maturity evaluation. J. Environ. Qual. 30:222-228.

41. Yourman, L. F., and Jeffers, S. N. 1999. Resistance to benzimidazole and dicarboximide fungicides in greenhouse isolates of Botrytis cinerea. Plant Dis. 83:569-575. 